\title{
Breastfeeding: Health benefits and dietary recommendations
}

\author{
Ines Panjkota Krbavčićk, Anja Vukomanović
}

Laboratory for Food Chemistry and Biochemistry, Department of Food Quality Control, Faculty of Food Technology and Biotechnology, University of Zagreb, 6 Pierottijeva Street, 10000 Zagreb, Croatia

*Corresponding author: ipanjkota@pbf.hr

\begin{abstract}
Breastfeeding is a natural way of feeding a newborn as it provides all the essential nutrients necessary for appropriate growth and development. Also, it is a delicate period when the emotional and physical connection between mother and child is created, providing the child with a sense of security, relaxation, and tenderness. Under that, the devotion of institutions and various associations to raise social and health awareness and promote the importance of breastfeeding is constantly increasing. World Health Organization (WHO) recommends exclusive breastfeeding during the first six months of an infant's life, which provides the child many short-and long-term benefits. When talking about benefits, the emphasis is put primarily on the wellbeing of the child, while the focus on the needs of a nursing mother should be of equal importance. The period of lactation and breastfeeding demands the mother's greater energy intake than the period of the last three-semester of pregnancy to meet all micro- and macronutrient needs of mother and child. The volume and the composition of milk, respectively the quality of infant's nutrition, partially depends on the quality of the mother's nutrition, and partially on the mother's physical supplies from which nutrients are being compensated in the case of a dietary deficit. To avoid the negative effects of lactation and breastfeeding on the nutritional and health status of the mother in upcoming periods of life, it is crucial to give special attention to various, balanced, and energy-satisfying nutrition. Although the primary goal is to achieve the recommended intake of all essential nutrients by food intake, in cases of unbalanced nutrition, health limitations, or practicing restrictive diets, the use of dietary supplementation is needed. Because of the biological needs and fortified deficits, in dietary supplements for pregnant women could often be found iron, calcium, zinc, iodine, folate, and vitamins $B_{12}$, C and $D$.
\end{abstract}

Keywords: lactation, breastfeeding, nutrition, supplementation

\section{Sažetak}

Dojenje je prirodan način hranjenja novorođenčeta jer mu pruža sve neophodne hranjive tvari potrebne za odgovarajući rast $i$ razvoj. Također, dojenje je osjetljivo razdoblje kada se stvara emocionalna i tjelesna veza između majke i djeteta, pružajući djetetu osjećaj sigurnosti, opuštenosti $i$ nježnosti. U skladu s navedenim, posvećenost institucija i raznih udruga za podizanje društvene $i$ zdravstvene svijesti te promicanje važnosti dojenja neprestano rastu. Svjetska zdravstvena organizacija (SZO) preporučuje isključivo dojenje tijekom prvih šest mjeseci djetetovog života, što djetetu pruža brojne kratkoročne i dugoročne koristi. Kada se govori o koristima dojenja, naglasak se stavlja prvenstveno na dobrobit djeteta, dok bi potrebe dojilja trebale biti od jednake važnosti. Razdoblje laktacije i dojenja zahtijeva veći majčin energijski unos u usporedbi s razdobljem posljednjeg tromjesečja trudnoće kako bi se zadovoljile sve potrebe majke i djeteta za mikro-i makronutrijentima. Količina i sastav mlijeka, odnosno kvaliteta prehrane dojenčeta, dijelom ovisi o kvaliteti majčine prehrane, a dijelom o majčinim tjelesnim zalihama iz kojih se nadoknađuju hranjive tvari u slučaju nedovoljnog prehrambenog unosa. Kako bi se izbjegli negativni učinci laktacije i dojenja na prehrambeni i zdravstveni status majke u nadolazećim životnim razdobljima, presudno je posvetiti posebnu pozornost raznovrsnoj, uravnoteženoj i energijski zadovoljavajućoj prehrani. Iako je primarni cilj postići preporučeni unos svih esencijalnih hranjivih sastojaka prehranom, u slučajevima neuravnotežene prehrane, zdravstvenih problema ili prakticiranja restriktivne dijete, potrebna je primjena dodataka prehrani. Zbog povećanih bioloških potreba $i$ utvrđenih deficita, $u$ dodacima prehrani za trudnice često se mogu naći željezo, kalcij, cink, jod, folat te vitamini $B_{12}, C i D$.

Ključne riječi: laktacija, dojenje, prehrana, suplementacija

\section{Introduction}

The awareness of the importance of breastfeeding is at its peak. Today, breastfeeding represents one of the key strategies for improving public health. Mother's milk is considered the perfect food for an infant because it is safe, has a unique composition, and provides all necessary nutrients for an infant (Agostoni et al., 2009; WHO, 2009a; AAP, 2012).

Planning of a mother's dietary intake is not over by ending a pregnancy, but it continues during lactation. Lactation is a very delicate period in which energy and dietary intake must be planned both for the optimal growth and physical and immunological development of an infant and for the mother's wellbeing (Institute of Medicine, 2006; WHO, 2009a). Infant's growth development depends on breastfeeding and nutrients gained from mother's milk. In other words, if a mother does not ensure everything that is needed for her and the infant's wellbeing, the primary goal will be to ensure the nutritional needs of an infant at the expense of maternal body supplies (WHO, 2009a). Only in cases where contraindications for breastfeeding are present, infant formulas become the main diet for an infant (WHO, 2009b).

This review study aimed to emphasize the importance of breastfeeding and its impact on mother's and infant's wellbeing, give insight into the composition of milk and provide recommendations for maternal nutrition and supplementation during the period of lactation. 


\section{Breastfeeding recommendations}

Breastfeeding and breast milk are the global standards for infant feeding (Agostoni et al., 2009; AAP, 2012; WHO, 2009a). Today's tendency is to follow recommendations and implement exclusive breastfeeding as long as possible. Exclusive breastfeeding implies to the period of feeding when ,infant only receives breast milk without any additional food or drink, not even water" (WHO, 2009a). WHO and UNICEF recommend initiation of breastfeeding in the first hour of newborns life, exclusive breastfeeding during the first six months of infant's life and adding complementary foods from the age of 6 months with continued breastfeeding during the first two years of infant's life (UNICEF, 2005a; WHO, 2009a). Official recommendations of the Croatian Pediatric Society and the American Academy of Pediatrics (AAP) are exclusive breastfeeding during the first 6 months of age with adding complementary foods and continued breastfeeding during the first year of an infant's life or longer if wanted (Pavičić Bošnjak et al., 2005; AAP, 2012). Croatian national recommendations suggest complementary feeding with continued breastfeeding from 4 months of infant's age (Kolaček et al., 2010).

\section{World and Croatian breasfeeding statistics}

Despite recommendations, globally there are $34.8-38.0 \%$ exclusively breastfed infants during the first 6 months of life (UNICEF, 2005a; WHO, 2009a), while there are $39.0 \%$ of breastfed 2-year-old infants (UNICEF, 2005a). According to WHO, the European region has one of the lowest rates of exclusive breastfeeding compared to other world regions. It was estimated in the period 2006 - 2012 that there were 25 $\%$ of exclusively breastfed infants in the first 6 months of life with rates of exclusive breastfeeding rapidly decreasing between $4-6$ months of age (WHO, 2018). Data from 2011 from the WHO Regional Office for Europe pointed out that Croatia is in the European top by the prevalence of exclusive breastfeeding under 6 months of age. In Croatia, $76 \%$ of infants were exclusively breastfed by the age of $0-2.9$ months and $54 \%$ by the age of 3-5.9 months (WHO, 2007). Research conducted among 11 European countries (including Croatia) showed that 56-98 $\%$ of infants are fed with human milk right after birth, while $38-71 \%$ are being breastfed and $13-39 \%$ exclusively breastfed at the age of 6 months (Theurich et al., 2019). Statistical data from 2019 of the Croatian Institute of Public Health (CIPH) showed increased rates of exclusive breastfeeding: there are $61.6 \%$ of infants exclusively breastfed in the first 5 months of life and $19.1 \%$ between $6-11$ months of age (CIPH, 2020).

\section{Strategies for promoting breastfeeding}

Optimal feeding during a child's first two years of life represents the base for its appropriate growth and development, preventing malnutrition and increasing infant's survival (WHO, 2009a). Many global initiatives and strategies are actively promoting breastfeeding and raising social awareness about its importance in child's short- and long-term benefits, what showed results in the developed world by rising rates of exclusive breastfeeding from $33 \%$ in 1996 to $37 \%$ in 2006 (WHO, 2009a). The Baby-Friendly Hospital Initiative (BFHI) was launched by WHO and UNICEF in 1991 to provide support to mothers and promote breastfeeding as the standard infant feeding in all maternities (UNICEF, 2005b). To fulfill the demands of BFHI, hospitals must implement Ten steps to successful breastfeeding (UNICEF, 2005b) and follow the International Code of Marketing of Breast-milk Substitutes (WHO, 1981). The Code protects breastfeeding and lactating mothers, prevents intrusive marketing of breastmilk substitutes and emphasizes the importance of mother's milk as the number one food for infants. The Global strategy for infant and young child feeding (WHO, 2003) from 2002 draws attention to the feeding practices, the importance of nutrition in improvement of child's quality of life and reduction of mortality among children, aspiring to reach the number of $50 \%$ exclusively breastfed infants younger than 6 months by 2025. Croatia is actively participating in BFHI from 1993 and today every hospital in Croatia carries the title of Baby-Friendly Hospital. Croatia signed the Strategy in 2018 and now is obligated to promote exclusive breastfeeding during mother's stay in all national University Hospitals and after, during the first 6 months of infant's life.

\section{Impact of breastfeeding on infant's and mother's health}

Breastfeeding has many short- and long-term positive health impacts important for infant's and mother's wellbeing. Breastfeeding reduces postpartum bleeding after delivery and can be used as ,natural contraception" as it delays menstruation and the possibility of conception (lactational amenorrhoea). Also, research showed that mothers who stop breastfeeding early are more likely to develop postnatal depression. In the long-term, it reduces the risk of ovarian, endometrial, and breast cancer and reduces the risk of obesity, osteoporosis, coronary heart disease, and diabetes type 2 (WHO, 2003; UNICEF, 2005a; Horta and Victoria, 2013). In infants, breastfeeding reduces the risk of infectious diseases and developing chronic diseases later in life (obesity, diabetes, hypercholesterolemia, hypertension, asthma, cardiovascular disease, chron disease, atopic dermatitis, etc), allergies, gastrointestinal and respiratory infections. Breastfeeding positively influences an infant's emotional, social, cognitive, and motor development (WHO, 2003; UNICEF, 2005a; Agostoni et al., 2009).

\section{Composition of human milk}

Human milk is characterized by its unique composition. It is the optimal food for infants providing all micro- and macronutrients necessary for infant's growth and development (Agostoni et al., 2009; Martin et al., 2016; Hojsak, 2017a). The main composition of milk is $87 \%$ water, $7 \%$ lactose, $3.8 \%$ fat, and $1.0 \%$ protein, while it also contains minerals, vitamins, trace elements, hormones, enzymes, essential fatty acids, antimicrobial components, immune components (such as leukocytes, oligosaccharides, nucleotides, cytokines, $\operatorname{IgA}$, etc.) and other bioactive compounds. Also, mother's milk differs from the compositions of every infant formula and milk from other mammals. The composition of a mother's milk is changeable and it depends on many factors. There are three types of human milk: colostrum, transitional and mature milk. Colostrum is produced at the end of the pregnancy and represents the perfect food for babies by which feeding should be initiated in the first hour of a newborns' life. In the first few days, it should provide the baby primarily with proteins, immune components, oligosaccharides, and developmental factors. During 5-14 days of an infant's life milk has the widest variety of substances and is characterized as transitional. During that period, the composition of the milk gradually changes, protein and immune cells concentration decrease while carbohydrates and fat increase, ending the process by achieving the composition of mature milk. The production of mature milk significantly increases compared to colostrum and transitional milk because of the increasing need for a child's proper development. Foremilk and hindmilk can also be differed by their composition - foremilk satisfies the baby's thirst and is higher in lactose, while foremilk satisfies the baby's energy needs as it is higher in fat (Agostoni et al., 2009; Martin et al., 2016; Hojsak, 2017a; Garwolińska et al., 2018). Mother's milk during exclusive breastfeeding entirely satisfies the baby's thirst and no additional water intake is needed (Hojsak, 2017a). Water intake change according to the infant's age, from $120-150 \mathrm{~mL} / \mathrm{kg} /$ day for a one-month-old baby to $80-120 \mathrm{~mL} / \mathrm{kg} /$ day for a one-year-old baby (Jadrešin, 2017). Water should be incorporated into the baby's dietary intake to compensate for water from mother's milk in cases when breastfeeding is reduced because of complementary feeding or stopped if the child is consuming solid foods (Hojsak, 2017a). According to its changeability, the composition varies according to 
the period of lactation and breastfeeding, infant's age and its changing needs, birth weight of the baby, time of the day, time of the last feeding, mother's age and diet, mother's weight gain during pregnancy, etc. (Agostoni et al., 2009; Martin et al., 2016; Hojsak, 2017a; Garwolińska et al., 2018).

\section{Macronutrients in human milk}

\section{Carbohydrates}

The main carbohydrate in human milk is lactose. Unlike protein and fat content, it has a stable concentration in mature mother's milk in the range of $67-78 \mathrm{~g} / \mathrm{L}$. The concentration of carbohydrates does not depend on the mother's weight, diet, and nutritional status, but correlates with the mother's milk production (Dror and Allen, 2018). Stable carbohydrate concentration has an important role in the absorption of calcium and other minerals and maintaining constant osmotic pressure in mother's milk (Martin et al., 2016). Human milk is rich in oligosaccharides which are used as nutrients for bacteria in infant's gastrointestinal tract, stimulating the development and growth of the infant (Dror and Allen, 2018; Garwolińska et al., 2018). The concentration of oligosaccharides in human milk decreases from $20-25 \mathrm{~g} / \mathrm{L}$ to $5-20 \mathrm{~g} / \mathrm{L}$ during milk maturing (Dror and Allen, 2018).

\section{Lipids}

Fat concentration in human milk is the most subjected to variations, with possible fluctuations in mature milk of $47 \%$ for $24 \mathrm{~h}$ (Dror and Allen, 2018). Fat provides $40-50 \%$ of the total infant's energy needs and is dependable on maternal diet, weight gain during pregnancy, breast fullness, time of the day, etc. (Martin et al., 2016; Dror and Allen, 2018). Lipids in human milk are specific by their composition. Triglycerides make $98 \%$ of total milk lipids and are specific because of the location of fatty acids on the glycerol chain. Oleic, palmitic, and linolenic acids are located by this exact order on glycerol carbon atoms with sn-1, sn2 , and sn-3 notations. This composition makes lipids from human milk more digestible for the infant compared to milk from other mammals. Also, this composition can not be found in infant formulas because it is impossible to reproduce it by industrial processes (Hojsak, 2017a; Garwolińska et al., 2018). Research showed that concentrations of saturated (SFA) and monounsaturated fatty acids (MUFA) in human milk vary less than polyunsaturated fatty acids (PUFA), eicosapentaenoic (EPA) and docosahexaenoic acid (DHA). EPA and DHA are dependable on the mother's diet (Martin et al., 2016; Dror and Allen, 2018).

\section{Proteins}

Protein content in milk depends on milk maturing, resulting in its concentration decreasing from $1.4-1.6 \mathrm{~g} / 100 \mathrm{~mL}$ in colostrum to 0.7 $0.8 \mathrm{~g} / 100 \mathrm{~mL}$ in mature milk after six months of lactation (Guo, 2014). Human milk contains the least protein and casein compared to the milk of other mammals, making it more digestible for the infant. The most common proteins are whey proteins, such as alpha-lactalbumin, lactoferrin, albumin, and lysosomes, while other non-protein compounds are urea, nucleotides, peptides, free amino acids, etc. (Hojsak, 2017a). Profile of free amino acids in the mother's milk changes according to the mother's dietary intake. The most common free amino acid during lactation is glutamate which is the precursor for glutamine. Glutamate and glutamine are presumed to have an important role in immune development, intestinal growth, and supplying nervous tissue with functional molecules (Dror and Allen, 2018).

\section{Micronutrients in human milk}

\section{Vitamins}

Concentrations of water-soluble vitamins (vitamin B complex and vitamin $\mathrm{C}$ ) in human milk react rapidly to dietary intake and supplementation. For example, the concentration of $\mathrm{B}_{6}$ increases in mother's milk within a few hours after supplementation. Only folate is independent of the mother's dietary and supplemental intake or body supplies and its concentration in milk is regulated on the homeostatic level. Vitamin $B_{12}$ is often deficient in mothers implementing restrictive diets, such as vegetarian, vegan, macrobiotic, etc. Other reasons could be pernicious anemia or health conditions causing malabsorption resulting from B12 deficiency. In these cases supplementation is effective. Colostrum has the highest concentration of vitamin $\mathrm{C}$, which is dropping during the period of lactation. Mothers who smoke or have diabetes have lower vitamin C milk concentrations (Dror and Allen, 2018).

Fat-soluble vitamins concentration in milk reacts slower on dietary and supplemental intake. The concentration of vitamin E in milk is decreasing during lactation, while vitamin D concentrations are lower in the milk of obese mothers. Both vitamin concentrations in milk can be influenced by dietary and supplement intake. In the case of vitamin A, research showed that supplementation is effective only in cases of malnourished mothers. Also, its inadequate concentration in the mother's milk is compensated by the mother's liver supplies. Because vitamin $\mathrm{K}$ does not pass the placental barrier easily, its concentration in milk is very low and can not be affected by dietary intake and supplementation (Dror and Allen, 2018).

\section{Minerals}

Concentrations of iron, copper, zinc, calcium, phosphorus, magnesium, and selenium in human milk are not dependent on the mother's nutrition and supplementation, except for iodine. In women with iron deficiency, lower concentrations of calcium and zinc in breast milk are found. Lower concentrations of zinc are also found in the milk of older women, while lower calcium concentrations are specific for lactating adolescents (Dror and Allen, 2018).

\section{Influences on milk production}

Milk production can be influenced by factors causing changes in composition, caloric, and quantitative values. The maternal diet has an influence on milk composition and volume in cases when a mother is malnourished or implementing a restrictive diet. The result is reduced milk volume but about the same proportions of carbohydrates, fat, and protein as in the milk of mothers with an adequate nutritional status. Milk volume and composition among malnourished women can be positively influenced by improving dietary intake and taking dietary supplements, while women with adequate nutritional status would not benefit from energy or protein supplements (Agostoni et al., 2009). Milk production and its caloric value would not be changed by exercise, mother's body mass index (BMI), mother's body weight, weight gain during pregnancy, and mother's body fat, while anxiety, stress, and smoking can decrease the production of milk (Kominiarek, 2016).

\section{Contraindications for breastfeeding}

There are not many contraindications for breastfeeding, but the mother's health condition can surpass the importance of breastfeeding and influence the infant's wellbeing. The main contraindication is maternal human immunodeficiency virus (HIV) infection, which can be transmitted to the infant through the mother's milk. In developed countries, HIV-infected mothers are advised to avoid breastfeeding, while the avoidance is often not possible in third world countries, where benefits of breastfeeding overcome the risk of infection (Agostoni et 
al., 2009; WHO, 2009a; AAP, 2012). WHO recommends replacement feeding instead of breastfeeding by mothers infected with HIV in cases when replacement feeding is ,acceptable, feasible, affordable, sustainable and safe". In cases when it is not possible to apply, exclusive breastfeeding is recommended (WHO, 2010). Contraindications for breastfeeding are herpes simplex lesions on the mother's breasts, T-cell lymphotropic virus (HTLV) type I or II infection, radioactive materials exposure, and medical therapy by applying diagnostic or therapeutic radioactive isotopes (Agostoni et al., 2009; AAP, 2012). Breastfeeding should not be stopped when the mother is infected with hepatitis A, B, and $\mathrm{C}$ because of the low risk of transmission. Health contraindications for breastfeeding for infants are galactosemia and metabolic disorders such as long-chain fatty acid oxidation and congenital lactase deficiency (Agostoni et al., 2009).

In a period of lactation, the choice of medication plays an important role for the mother because of its potential influence on the infant. Drugs can be found in mother's milk and their influence depends on drug dosage, the number of drugs excreted in mother's milk, and the absorption of drugs from mother's milk. The important factor is also if the mother is taking drugs as periodical or permanent therapy. As most of the drugs are not harmful to the baby, health professionals should choose appropriate therapy with minimal influence on the baby so that the mother can continue, and preventively monitor a child's physical functions (Agostoni et al., 2009; Hojsak, 2017a). Drugs that should not be used during breastfeeding are cytostatics, amiodarone, ergotamine, lithium, and iodides (Hojsak, 2017a).

\section{Dietary recommendations for women during period of lactation}

The main focus in planning nutrition and supplementation during lactation is adapting to the increased mother's and infant's needs. The estimated energy requirement (EER) in lactating women is based on women's health, wellbeing, and the secretion of milk and should cover all the energy needed for milk production. Although recommendations for Dietary Reference Intake (DRI) (Institute of Medicine, 2006) were used in this research, European Food Safety Authority (EFSA) recommendations (EFSA, 2019) could also be used as the reference dietary recommendations for lactating women. DRI recommendations differ between non-pregnant, pregnant, and lactating women (Institute of Medicine, 2006).

Recommendations for energy, micro- and macronutrient intake in lactating women are even higher than in pregnant women (Institute of Medicine, 2006; WHO, 2009a). According to WHO and RDA recommendations, EER (kcal) for lactating women is based on the EER values for non-pregnant women, with an additional $500 \mathrm{kcal}$ for 0-6 months postpartum (Institute of Medicine, 2006; WHO, 2009a) and $400 \mathrm{kcal}$ for 7-12 months postpartum (Institute of Medicine, 2006). AAP recommends additional $450-500 \mathrm{kcal} /$ day during the whole period of breastfeeding (AAP, 2012). This additional $500 \mathrm{kcal}$ per day is used for producing approximately $750 \mathrm{~mL}$ of milk (WHO, 2009a). If there is an intention of losing weight in 0-6 months postpartum, EER for lactating women can be reduced by $170 \mathrm{kcal}$. WHO recommends that energy intake for breastfeeding women should be $10 \%$ higher for physically inactive and $20 \%$ higher for moderately or very active women, compared with non-lactating women. Also, the production of human milk will not be affected in cases of moderate malnourishment of the mother because she will start to spend her body supplies to preserve the quality and quantity of milk. The quantity of breast milk will be negatively affected only in cases of greater malnourishment (Institute of Medicine, 2006).

DRI for each macronutrient for lactating women is presented in Table 1 and compared with recommended nutrient intake for non-pregnant and pregnant women (Institute of Medicine, 2006), showing that protein and carbohydrate intake increase during lactation. DRI sets recommendations for lactating women on $210 \mathrm{~g}$ /day of carbohydrates. It is suggested that the intake of added sugar should not be higher than $25 \%$ of total daily energy intake. The recommendation for total fiber intake is $29 \mathrm{~g} /$ day for lactating women. Research showed that fiber can interfere with the absorption of calcium, magnesium, iron, and zinc when ingested together and decrease their absorption. DRI recommendation is not determined for total fat intake but sets recommendations on $13 \mathrm{~g} /$ day for linolenic acid and $1.3 \mathrm{~g} /$ day for $\alpha$-linolenic acid (Institute of Medicine, 2006). Concentrations of arachidonic acid (AA), EPA and DHA in human milk are dependent on the mother's dietary and supplemental intake (Martin et al., 2016). According to that, mothers should achieve the intake of DHA of $200-300 \mathrm{mg} /$ day to ensure its sufficient concentration in milk, which can be met by the consumption of 1-2 portions of fish per week (AAP, 2012). This intake of DHA will achieve levels of $0.3-0.35 \%$ DHA in mother's milk (Martin et al., 2016). Water intake during lactation should be $3.8 \mathrm{~L}$ /day of total water which includes all water from food, beverages, and drinking water and represents about $3.1 \mathrm{~L}$ or 13 cups of total beverages (Institute of Medicine, 2006).

Intake of essential amino acids for lactating women should be the highest in the period of lactation (Table 2) as the protein profile in human milk can be influenced by the mother's nutrition (Dror and Allen, 2018). Intake of essential amino acids depends specifically on nutrition and supplementation as these amino acids are not synthesized in the human body (Institute of Medicine, 2006).

DRI for each micronutrient for lactating women is shown in Table 3 and compared with recommended nutrient intake for non-pregnant and pregnant women. For example, recommended calcium intake is the same for pregnant and lactating women. In other words, a higher intake of calcium during lactation will not stop the depletion of maternal body supplies of calcium, but the proper nutrition and potentially needed supplementation will lead to the restoration of calcium supplies (Institute of Medicine, 2006). Intake of micronutrients should be adapted to recommendations as their concentrations in human milk can be subjected to changes. These changes according to mother's nutrition and

Table 1. Comparison of Dietary Reference Intakes (DRI) for macronutrients for non-pregnant, pregnant and lactating women (Institute of Medicine, 2006)

\begin{tabular}{|l|c|c|c|}
\hline Nutrient & Non-pregnant* & Pregnancy* & Lactation* $^{*}$ \\
\hline Carbohydrates (g/day) & 130 & 175 & 210 \\
\hline Total fiber (g/1000 kcal) [g/day] & $14[25]$ & $14[28]$ & $14[29]$ \\
\hline Proteins (g/kg/day) [g/day] & $0.8[46]$ & $1.1[71]$ & $1.3[71]$ \\
\hline Total fats (g/day) & $\mathrm{ND}^{\times}$ & $\mathrm{ND}^{\times}$ & $\mathrm{ND}^{\times}$ \\
\hline Linolenic acid (g/day) & 12 & 13 & 13 \\
\hline$\alpha$-Linolenic acid (g/day) & 1.1 & 1.4 & 1.3 \\
\hline
\end{tabular}

*recommendations for women above 18 years old

${ }^{x}$ not determined 
Table 2. Comparison of Recommended Dietary Allowances (RDA) for essential amino acids for non-pregnant, pregnant and lactating women (Institute of Medicine, 2006)

\begin{tabular}{|l|c|c|c|}
\hline Essential amino acids (mg/kg/day) & Non-pregnant* & Pregnancy ${ }^{\times}$ & Lactation $^{\times}$ \\
\hline Histidine & 14 & 18 & 19 \\
\hline Isoleucine & 19 & 25 & 30 \\
\hline Leucine & 42 & 56 & 52 \\
\hline Lysine & 38 & 51 & 26 \\
\hline Methionine + cysteine & 19 & 25 & 51 \\
\hline Phenylalanine + tyrosine & 33 & 44 & 30 \\
\hline Threonine & 20 & 26 & 9 \\
\hline Tryptophan & 5 & 7 & 35 \\
\hline Valine & 24 & 31 & \\
\hline *recommendations for women aged above 19 years old & & ${ }^{\times}$recommendations for women of all ages \\
\hline
\end{tabular}

Table 3. Comparison of Recommended Dietary Allowances (RDAs) for micronutrients for non-pregnant, pregnant and lactating women (Institute of Medicine, 2006)

\begin{tabular}{|c|c|c|c|}
\hline Nutrient & Non-Pregnant* & Pregnant* & Lactation* \\
\hline Vitamin $A(\mu \mathrm{g} / \mathrm{d})$ & 700 & 770 & 1300 \\
\hline Vitamin $D(\mu \mathrm{g} / \mathrm{d})$ & 5 & 15 & 15 \\
\hline Vitamin E (mg/d) & 15 & 15 & 19 \\
\hline Vitamin $\mathrm{K}(\mu \mathrm{g} / \mathrm{d})$ & 90 & 90 & 90 \\
\hline Folate $(\mu \mathrm{g} / \mathrm{d})$ & 400 & 600 & 500 \\
\hline Niacin (mg/d) & 14 & 18 & 17 \\
\hline Riboflavin (mg/d) & 1.1 & 1.4 & 1.6 \\
\hline Thiamin (mg/d) & 1.1 & 1.4 & 1.4 \\
\hline Vitamin $B_{6}(\mathrm{mg} / \mathrm{d})$ & 1.3 & 1.9 & 2 \\
\hline Vitamin $\mathrm{B}_{12}(\mu \mathrm{g} / \mathrm{d})$ & 2.4 & 2.6 & 2.8 \\
\hline Vitamin C (mg/d) & 75 & 85 & 120 \\
\hline Calcium (mg/d) & 1,000 & 1,000 & 1,000 \\
\hline Iron (mg/d) & 18 & 27 & 9 \\
\hline Phosphorus (mg/d) & 700 & 700 & 700 \\
\hline Selenium $(\mu \mathrm{g} / \mathrm{d})$ & 55 & 60 & 70 \\
\hline Zinc (mg/d) & 8 & 11 & 12 \\
\hline Copper $(\mu \mathrm{g} / \mathrm{d})$ & 900 & 1000 & 1300 \\
\hline $\operatorname{Iodine}(\mu \mathrm{g} / \mathrm{d})$ & 150 & 220 & 290 \\
\hline Magnesium (mg/d) & 320 & 350 & 310 \\
\hline
\end{tabular}

*recommendations for women above 18 years old 
dietary supplementation are explained in one of the previous sections, Micronutrients in human milk.

\section{Recommendations for supplementation for women during the period of lactation}

There is no universal recommendation for dietary supplementation for lactating women. Although a healthy diet is the foundation in planning nutrition and satisfying all nutritional needs of the mother and her infant, deficits of micro- and macronutrients are possible as the mother's needs are increased during pregnancy and lactation. In that case, supplementation should be prescribed individually, depending on a woman's health condition, implemented restrictive or eliminating diet, and other factors causing dietary deficits. To preventively avoid those deficits, it is prescripted in many cases that breastfeeding women should continue to use prenatal dietary supplements (AAP, 2012; Kominiarek, 2016). Women who are breastfeeding multiple infants should consider supplementation with magnesium and calcium due to the increased production of milk. Special attention should be given to iron - calcium, and iron - zinc interactions while supplementing during lactation. The absorption of zinc can be inhibited if taking iron and zinc supplements at the same time. This can be avoided by taking supplements before or after a meal (Institute of Medicine, 2006).

Supplementation is often needed when implementing restrictive diets, such as vegetarian and vegan. Research showed there is a possible deficit of energy, proteins, vitamin $\mathrm{B}_{12}$, vitamin $\mathrm{D}$, zinc, iron, calcium, and omega-3 fatty acids, that can influence adequate growth and development of breastfeeding infant (Vranešić Bender, 2017). American Dietetic Association (ADA) (Craig et al., 2009), Canadian Pediatric Society (CPS) (Amit et al., 2010), and the European Society for Paediatric Gastroenterology, Hepatology and Nutrition (ESPGHAN) (Agostoni et al., 2009) stated that vegetarian and vegan diets, if adequately planned and applied, are appropriate during pregnancy and lactation. Human milk can be insufficient with vitamin $\mathrm{B}_{12}$, depending on the mother's dietary intake. Vitamin $B_{12}$ supplementation of vegan mothers during lactation is highly recommended in the amount of $0.4-0.5 \mathrm{mcg} / \mathrm{day}$ as inadequate vegan nutrition can have a long-lasting impact on the mother's and child's wellbeing (Agostoni et al., 2009; Niseteo, 2017). Also, vegan mothers should use DHA supplements in the case of inadequate dietary intake (AAP, 2012).

\section{Developing child's food preferences during pre-natal period and breastfeeding}

Flavor experiences and food preferences of an infant start to develop during pregnancy. During the later stage of pregnancy, the fetus swallows and inhales amniotic fluid what makes it exposed to flavors of food that the mother consumed. Fetus experiences those flavors and odors with the same intensity as the infant experiences mother's milk and solid foods and this exposure can determine its later food choices. Also, if the fetus is frequently exposed to sour or bitter flavors through the amniotic fluid and later through the mother's milk, it will get used to it and accept it more easily when introducing solid foods (Mennella et al., 2017). Research showed that a mother's varied diet during breastfeeding can protect an infant from obesity later in life by influencing its food preferences and food choices during childhood and adolescent periods (De Cosmi et al., 2017). Breastfed infants were less picky and wanted to try new foods if the mother consumed a varied diet because they were introduced to many flavors through mother's milk. Also, infants fed with formula tend to be more picky eaters later in life because they have a less varied diet where flavors can differ depending on the type of the used formula (Mennella, 2014).

\section{Discussion}

Healthy nutrition should be the basis for assessing the mother's and infant's nutritional status. Advice for breastfeeding mothers is general - women are advised to eat a variety of food and include fresh and local ingredients, while energy intake should be increased to meet all needs necessary for the production of milk. In cases of insufficient mother's dietary intake, milk retains optimal composition adapted to the infant's needs (Agostoni et al., 2009; WHO, 2009a). When economic and household conditions are not entirely appropriate for infant feeding, mother's milk represents the safest, most efficient, and most complete food for the child (WHO, 2009a).

Although diet should be primary in maintaining healthy nutrition, in some cases supplementation is recommended. Supplementation should be considered when a mother is implementing a restrictive nutritional regime because of her lifestyle, personal believes, and/or health conditions, such as food allergies, food intolerances, etc. Such regimes result in avoiding certain foodstuffs or food groups and possible macroand micronutrient deficiencies (Agostoni et al., 2009; Vranešić Bender, 2017).

Maternal vitamin $\mathrm{B}_{12}$ supplementation is recommended when implementing a restrictive diet, such as a plant-based diet, but it is also recommended for infants because vitamin $\mathrm{B}_{12}$ deficiency can cause irregular neurological development and megaloblastic anemia (Agostoni et al., 2009; Niseteo, 2017). Plant-based diets include the risk of essential amino acid deficiency and lower protein quality compared to animal proteins, which can be avoided by a complementary mixture of plant proteins (Institute of Medicine, 2006).

Chronic deficiency of vitamin D is present in $20-40 \%$ of pregnant and lactating women and it can be defined as a public health problem. Maternal vitamin D deficiency influences infants causing insufficient intake of vitamin D through mother's milk, especially for exclusively breastfed infants. The mother's serum concentration of vitamin D can be recovered by oral supplementation therapy which proved very efficient and resulted in increased vitamin D concentration in milk, sufficient for meeting the infant's requirements. Research showed that supplementation with a minimum of $2000 \mathrm{IU} /$ day of vitamin D can increase mother's and infant's serum vitamin D levels, while 4000 IU/day can satisfy mother's and infant's needs. Optimal vitamin D supplementation for lactating women should be further investigated (Dawodu and Tsang, 2012).

Iodine deficiency is also recognized as a global public health problem. Iodine needs in pregnancy are almost $50 \%$ higher when compared to the non-pregnancy period. The main reason is a precaution because the human body is unable to synthesize iodine and iodine intake depends on dietary and supplemental intake (Institute of Medicine, 2006). The research confirmed the importance of a mother's dietary intake of iodine as its deficit can influence an infant's cognitive development. However, additional research is needed in determining the optimal concentration of supplementation because it's excessive intake can negatively affect an infant's health and condition of the fetal thyroid gland (Zhou et al., 2013). Also, there are risks and concerns about excessive mercury intake when consuming fish rich with DHA. That can be avoided by supplementation, which in this case represents a safe and practical source of fatty acids during pregnancy and lactation (AAP, 2012).

During a period of pregnancy, the infant creates body supplies of iron, sufficient for the first months of life. Infant's body supplies of iron are spent after 4 - 6 months postpartum and in that period infant's risk of iron deficiency and anemia is increased. Mother's milk contains iron of high bioavailability but in low concentrations, which are not adequate for fulfilling all infant needs (Garwolińska et al., 2018; Hojsak, 2017b). Research showed that exclusively breastfed children can develop iron deficiency at age of 4 months (Dube et al., 2010). It shows the need for complementary feeding with iron-rich food in 6 months old infants (Hojsak, 2017b) and in some infants even sooner than officially recommended (Dube et al., 2010). Also, serum concentrations of iron were found equally appropriate in exclusively breastfed infants and 
infants fed with milk formulas, which shows differences in bioavailability of iron between human milk and infant formulas. Although formulas contain higher concentrations of iron $(0.84 \mathrm{mg} / 100 \mathrm{~mL})$ compared to breast milk $(0.058 \mathrm{mg} / 100 \mathrm{~mL})$, breastfed infants will use more dietary iron than formula-fed infants (Dube et al., 2010).

Women often restrict their dietary intake and avoid certain foodstuffs. Mothers link their diet with a child's behavior, such as abdominal pain, crying, colic, bloating, rash, etc., and try to influence or avoid that kind of behavior by dietary restrictions. Those restrictions can get out of hand and result in unnecessary limitations of whole food groups from a mother's diet. The most commonly avoided foodstuffs are cruciferous vegetables, citruses, onions, legumes, gluten, spicy foods, caffeine, etc. According to research, there is no need for a mother's dietary restrictions just because of precaution. The mother should keep track of her diet and infant's reactions to milk. Certain foodstuffs should be eliminated from the mother's diet only in cases when reactions of an infant to certain food are noticed. Medical conditions, such as mother's or infant's food intolerances and allergies, are also justified reasons for implementing restrictive diets (Kidd et al., 2019). Also, research showed there is no association between breastfeeding and developing allergies in infants (Lodge et al., 2015). Furthermore, there is no unified opinion about the effectiveness of the method of excluding allergens from the maternal diet. Because of precaution or self-diagnosis, mothers implement restrictive diets to avoid $\operatorname{IgE}$ and non-IgE mediated food allergies in infants. Although some allergens are found in mother's milk, it is not clear why do some infants with diagnosed allergies react to allergens from mother's milk, while others do not (Boyce et al., 2010).

The important role of mother's diet is emphasized through research and proved that breastfed children are more attracted to new flavors, accept them more easily, have a greater food intake, and consume a greater variety of fruit and vegetables, which is proved to be related with prevention of obesity later in life (Ventura, 2017). Research made on 97 mothers and thair infants showed that infants accepted vegetable flavored cereals more easily if their mothers were drinking vegetable juices during breastfeeding (Mennella et al., 2017). Also, an infant can detect different flavors in the mother's milk according to the time of the mother's ingestion. The taste of garlic, alcohol, and vanilla can be detected in milk within a few hours, and carrot juice within a few days after the mother's ingestion (Spahn et al., 2019).

\section{Conclusions}

In conclusion, the period of breastfeeding is undoubtedly one of the most important aspects of infancy. By providing all necessary nutrients and satisfying an infant's energy needs, the mother's milk enables proper child growth and development. To maintain child's and mother's health during the period of lactation, balanced nutrition with increased energy and micronutrient intake is recommended for the mother. Proper education and consultations with nutritionists should be included in maintaining the mother's healthy nutrition. Supplementation recommendations are always individual and adjusted to the mother's health status and nutrition. Supplementation is usually recommended for mothers implementing restrictive diets that could lead to nutritional deficits. Most commonly, supplementation is recommended for vitamin $\mathrm{B}_{12}$, vitamin $\mathrm{D}$, folate, iodine, zinc, iron, calcium, and omega-3 fatty acids.

\section{References}

AAP (2012) Breastfeeding and the use of human milk. Pediatrics, 129 (3) 827-841.

Agostoni C., Braegger C., Decsi T., Kolacek S., Koletzko B., Michaelsen K. F., Mihatsch W., Moreno L. A., Puntis J., Shamir R., Szajewska H., Turck D., Van Goudoever J. (2009) Breast-feeding: A commentary by the ESPGHAN Committee on Nutrition. Journal of Pediatric Gastroenterology and Nutrition, 49 (1) 112-125.

Amit M., Cummings C., Grueger B., Feldman M., Lang M., Grabowski J., Wong D., Greig A., Patel H. (2010) Vegetarian diets in children and adolescents. Paediatrics and Child Health, 15 (5) 303-314.

Boyce J. A., Jones S. M., Rock L., Sampson H. A., Cooper S. F., Boyce S., Al E. T. (2010) Guidelines for the diagnosis and management of food allergy in the United States: Report of the NIAID-sponsored expert panel. Journal of Allergy and Clinical Immunology 126 (6) 1-58.

CIPH (2020) Croatian Health Statistics Yearbook 2019 (web edition). Available on: https://www.hzjz.hr/hrvatski-zdravstveno-statisticki-ljetopis/ hrvatski-zdravstveno-statisticki-ljetopis-za-2019/. Accessed on: 15.01.2021.

Craig W. J, Mangels A. R, American Dietetic Association (2009) Position of the American dietetic aAssociation: vegetarian Diets adequate for all stages of life. Journal of the American Dietetic Association, 109 (7) 1266-1282.

Dawodu A., Tsang R. C. (2012) Maternal Vitamin D Status : Effect on Milk Vitamin D Content and Vitamin D Status. Advances in Nutrition: An International Review Journal, 3 353-361.

De Cosmi V., Scaglioni S., Agostoni C. (2017) Early taste experiences and later food choices. Nutrients, 9 (2) 1-9.

Dror D. K., Allen L. H. (2018) Overview of nutrients in humanmilk. Advances in Nutrition, 9 278-294.

Dube K., Schwartz J., Mueller M. J., Kalhoff H., Kersting M. (2010) Iron intake and iron status in breastfed infants during the first year of life. Clinical Nutrition, 29 (6) 773-778.

EFSA (2019) Dietary reference values. Available on: https://www.efsa.europa.eu/en/topics/topic/dietary-reference-values. Accessed on: 09.04.2021. Garwolińska D., Namieśnik J., Kot-Wasik A., Hewelt-Belka W. (2018) Chemistry of Human Breast Milk - A Comprehensive Review of the Composition and Role of Milk Metabolites in Child Development. Journal of Agricultural and Food Chemistry, 66 (45) 11881-11896.

Guo M. (2014) Human Milk Biochemistry and Infant formula (1st ed.). Woodhead Publishing, Sawston, Cambridge, UK.

Hojsak, I. (2017a) Dojenje. In: Kolaček S., Hojsak I., Niseteo T. (1st ed): Prehrana u općoj i kliničkoj pedijatriji, str. 135-142. Medicinska naklada, Zagreb, Croatia.

Hojsak, I. (2017b) Dohrana. In: Kolaček S., Hojsak I., Niseteo T. (1st ed): Prehrana u općoj i kliničkoj pedijatriji, str. 150-156. Medicinska naklada, Zagreb, Croatia.

Institute of Medicine (2006) Dietary reference intakes: The Essential Guide to Nutrient Requirements. National Academies Press, Washington, USA. Jadrešin, O. (2017) Prehrambene potrebe: tekućina i elektroliti. In: Kolaček S., Hojsak I., Niseteo T. (1st ed): Prehrana u općoj i kliničkoj pedijatriji, str. 49-55. Medicinska naklada, Zagreb, Croatia.

Kidd M., Hnatiuk M., Barber J., Woolgar M. J., Mackay M. P. (2019) Something is wrong with your milk. Canadian Family Physician, 65 (3) 204-211.

Kolaček S., Barbarić I., Despot R., Dujšin M., Jelić N., Hegeduš-Jungvirth M., Mišak Z., Peršić M., Pinotić Lj., Radman D., Senečić-Čala I., Tješić Drinković D., Žaja O. (2010) Nutrition of healthy infants: recommendations of the Croatian Society of Pediatric Gastroenterology, Hepatology and Nutrition. Paediatria Croatica, 54 (1) 53-56.

Kominiarek M. (2016) Nutrition Recommendations in Pregnancy and Lactation. Medical Clinics of North America, 100 (6) $1199-1215$. 
Lodge C., Tan D., Lau M., Dai X., Tham R., Lowe A., Bowatte G., Allen K., Dharmage, S. (2015) Breastfeeding and asthma and allergies: A systematic review and meta-analysis. Acta Paediatrica, International Journal of Paediatrics, 104 38-53.

Martin C. R., Ling P. R., Blackburn G. L. (2016) Review of infant feeding: Key features of breast milk and infant formula. Nutrients, 8 (5) 1-11.

Mennella J. A. (2014) Ontogeny of taste preferences: basic biology and implications for health. The American Journal of Clinical Nutrition, 99 704-711.

Mennella J. A., Daniels L. M., Reiter A. R. (2017) Learning to like vegetables during breastfeeding: A randomized clinical trial of lactating mothers and infants. American Journal of Clinical Nutrition, 106 (1), 67-76.

Niseteo, T. (2017) Alternativna prehrana djece: vegetarijanska, makrobiotička, veganska. In: Kolaček S., Hojsak I., Niseteo T. (1st ed): Prehrana u općoj i kliničkoj pedijatriji, str. 175-186. Medicinska naklada, Zagreb, Croatia.

Pavičić Bošnjak A., Blašković Kokeza J., Dujmović A., Hegeduš Jungvirth M., Letica Protega N., Obradović K., Grgurić J. (2005) Preporuke za promicanje dojenja Hrvatskog Pedijatrijskog Društva. PAEDIATRIA CROATICA, 49 (4) 261-263.

Spahn J. M., Callahan E. H., Spill M. K., Wong Y. P., Benjamin-Neelon S. E., Birch L., Black M. M., Cook J. T., Faith M. S., Mennella J. A., Casavale K. O. (2019) Influence of maternal diet on flavor transfer to amniotic fluid and breast milk and children's responses: A systematic review. American Journal of Clinical Nutrition, 109 1003-1026.

Theurich M. A., Davanzo R., Busck-Rasmussen M., Díaz-Gómez N. M., Brenna C., Kylberg E., Bærug A., McHugh L., Weikert C., Abraham K., Koletzko B. (2019) Breastfeeding rates and programs in europe: A survey of 11 national breastfeeding committees and representatives. Journal of Pediatric Gastroenterology and Nutrition, 68 (3) 400-407.

UNICEF (2005a) Breastfeeding. Available on: https://www.unicef.org/nutrition/index_24763.html. Accessed on: 15.01.2021.

UNICEF (2005b) Baby-Friendly Hospital Initiative. Available on: https://www.unicef.org/nutrition/index_24806.html. Accessed on: 15.01.2021.

Ventura A. K. (2017) Does Breastfeeding Shape Food Preferences? Links to Obesity. Annals of Nutrition and Metabolism, 70 (3) 8-15.

Vranešić Bender, D. (2017) Prehrana u trudnoći i dojenju. In: Kolaček S., Hojsak I., Niseteo T. (1st ed): Prehrana u općoj i kliničkoj pedijatriji, str. 166-174. Medicinska naklada, Zagreb, Croatia.

WHO (1981) International Code of Marketing of World Health Organization. Available on: https://www.who.int/nutrition/publications/code_english. pdf. Accessed on: 15.01.2021.

WHO (2003) Global strategy for infant and young child feeding. Available on: https://www.who.int/nutrition/publications/infantfeeding/9241562218/ en/. Accessed on: 15.01.2021.

WHO (2007) Nutrition, physical activity and prevention of obesity: Policy developments in the WHO European Region. Available on: https://apps. who.int/iris/handle/10665/107843. Accessed on: 15.01.2021.

WHO (2009a) Infant and young child feeding: Model chapter for textbooks for medical students and allied health professionals. Available on: https:// www.who.int/maternal_child_adolescent/documents/9789241597494/en/. Accessed on: 15.01.2021.

WHO (2009b) Acceptable medical reasons for use of breast-milk substitutes. Available on: https://www.who.int/nutrition/publications/infantfeeding/ WHO NMH NHD 09.01/en/. Accessed on: 15.01.2021.

WHO (2010) Guidelines on HIV and infant feeding. Available on: https://apps.who.int/iris/bitstream/handle/10665/44345/9789241599535_eng. pdf? sequence=1. Accessed on: 15.01.2021.

WHO (2017) Long-term health effects of breastfeeding: a systematic review. Available on: https://www.who.int/maternal_child_adolescent/ documents/breastfeeding_long_term_effects/en/. Accessed on: 15.01.2021.

WHO (2018) Implementation guidance: protecting, promoting and supporting breastfeeding in facilities providing maternity and newborn services: the revised baby-friendly hospital initiative. Available on: https://www.euro.who.int/en/countries/azerbaijan/publications/implementation-guidanceprotecting,-promoting-and-supporting-breastfeeding-in-facilities-providing-maternity-and-newborn-services-the-revised-baby-friendly-hospitalinitiative-2018. Accessed on: 15.01.2021.

Zhou S. J., Anderson A. J., Gibson R. A., Makrides M. (2013) Effect of iodine supplementation in pregnancy on child development and other clinical outcomes: A systematic review of randomized controlled trials. American Journal of Clinical Nutrition, 98 (5) 1241-1254. 